\title{
The Female and Male World in Croatian Proverbs
}

\author{
Goranka Blagus Bartolec, Ivana Matas Ivanković \\ Institute of Croatian Language and Linguistics, Zagreb, Croatia
}

\begin{abstract}
A B S T R A C T
Proverbs as concise textual structures are primarily defined as oral (folk) literary forms in which universal thoughts are expressed on the basis of individual experiences understandable to speakers of the language, i.e., of the social community in which they originated. In relation to, for example, idioms, the use of proverbs in today's public discourse is much rarer, and proverbs in Croatian are most often recorded in printed form, while online edited lexicographic sources of proverbs are rare. Folk customs, human character and physical features, social and religious values, the relation of human and nature are the most common motives in proverbs. Male-female relationships are also the subject of numerous proverbs. Given the past times when they were created, they can be considered the source of a stereotypical image of the status of women and men in society that exists in human consciousness. Based on proverbs with the component woman, grandmother, mother, daughter, sister, girlfriend, widow, father, son, husband..., this paper will analyze proverbs with the topic of male-female relations, e.g. Ljubav daj ženi, ali tajnu odaj samo majci $i$ sestri. (Give your love to your wife, but reveal the secret only to your mother and sister.), or proverbs referring to an individual feature attributed to a man or a woman, e.g., Kakvo drvo, takav klin, kakav otac takav sin. (Like tree, like wedge; like father, like son.)., Ženi sina kad hoćeš, a kćer kad možeš. (Marry a son when you want and a daughter when you can.). The analysis includes the following: 1. representation of proverbs in other lexicographic (printed and online sources), 2. representation of such proverbs in contemporary public discourse, 3. structural and semantic features of proverbs motivated by male-female relationships. In conclusion, the role of proverbs on the topic of male and female in the contemporary context is discussed-what is their perspective and whether the corpus has replaced traditional recorders and word of mouth today.
\end{abstract}

Key words: corpus, Croatian, female, male, proverbs

\section{Introduction: Proverbs in General}

Proverbs in Croatian are traditionally studied within literary theory and are determined as follows: 1 . they are short textual forms, 2. they are part of oral (folk) literature, 3 . they express universal thoughts based on individual experiences that are recognizable and understandable to language speakers, i.e., the social communities in which they arose, 4 . they are realized as a whole sentence (unlike idioms which, also as short textual forms, are part of a longer sentence). Although proverbs and idioms, according to the Croatian Language Curriculum, are included in the school program ${ }^{1}$ in the $4^{\text {th }}$ grade of primary school and the $1^{\text {st }}$ grade of high school, today's pupils use and understand them poorly. ${ }^{2}$ According to the Curriculum, proverbs and phrases are taught differently - proverbs are part of the literature and creativity program, and idioms are part of the Croatian language and communication program. Also, proverbs are less represented in everyday communication. Given that idioms are better known (for example, idioms are included both in the Croatian language state matura exam and in the Croatian language competition tests), speakers of Croatian use them more often than proverbs, which they generally perceive as archaic language forms, while idioms are still used today. In the rest of this paper, Croatian proverbs are translated into English as literally as possible since not all of them have equivalents in both languages.

\section{Current state: proverbs in contemporary Croatian} dictionaries

The list of proverbs in Croatian is traditionally given in dictionaries and collections of proverbs ${ }^{3-6}$. In these manuals, proverbs are listed according to the main word, most often nouns, adjectives or verbs ${ }^{3}$, according to the field of meaning ${ }^{4,5}$ or alphabetically, according to the initial word of the proverb ${ }^{6}$. Given the definition of a proverb as a tex-

Received for publication September 10, 2021 
tual form that presents thoughts and experiences recognizable to the community, dictionaries and collections of proverbs do not interpret their meaning because this approach assumes that speakers understand the content of the proverb. Proverbs are usually understandable (e.g., Ljubav daj ženi, ali tajnu odaj samo majci i sestri. (Give your love to your wife but reveal the secret only to your mother and sister.), Kad je rat, niko nikom nije brat. (When there is a war, no one is a brother to anyone.), $L i$ jepa je žena rijetko poštena. (A beautiful woman is rarely honest.), Ženskom poslu nigdje kraja. (There is no end to women's work.)), but there are also proverbs with figurative meaning whose content is not understandable without explanation or which can be interpreted as polysemous (e.g., Jako glumac, jače bubanj, a najjače nevjesta. (Strongly the actor, more strongly the drum, and most powerfully the bride.), Nije baba imala vraga pa namakla prase. (Grandma didn't have a devil, so she got a pig.), Ribarica po bonaci ruča, čobanica uvijek prvo sunca. (The fisherwoman has lunch on the dead calm sea, the shepherdess always before the sun.), Ženi se od kuce, pa makar od kučke. (You marry from home, even from a bitch.), Udrva što možeš dalje, a po djevojku što možeš bliže. (Go to the woods as far as you can and go for the girl as close as you can.), Ne vjeruj ženi, er se kako mjesec pjeni. (Don't trust a woman because she's foaming like the moon,), Dok diete ne zaplače, mati ga se ne sjeća. (Until the child cries, the mother does not remember him.)).

The inclusion of proverbs in general dictionaries of the Croatian language is exceptionally deficient concerning the representation of other strong multi-word conjunctions. Collocations, multi-word terms, and idioms are regularly included in a dictionary entry either within a particular meaning or at the end of the dictionary entry, as opposed to proverbs, that are not part of general dictionaries.

For this work, based on three modern Croatian dictionaries - Hrvatski jezični portal (Croatian Language Portal, hereafter HJP) ${ }^{7}$, Školski rječnik hrvatskoga jezika (School Dictionary of the Croatian Language, hereafter
ŠRHJ) ${ }^{8}$, Rječnik hrvatskoga jezika (Dictionary of the Croatian Language, hereafter RHJ) ${ }^{9}$ - it was researched how many proverbs are included in dictionaries under following headwords denoting male or female: otac (father), sin (son), kći (daughter), žena (woman/wife), babica (midwife), baba (grandma), djevojka (girl), gospodar (master), sluga (servant), majka (mother), otac (father), brat (brother), sestra (sister), kovač (blacksmith). The most proverbs are included in HJP - seven proverbs are recorded under the following headwords: baba (ک̌to je babi milo (što se babi htilo), to joj se $i$ snilo. (What grandma likes (what grandma wanted), she dreamed of it.), Nije baba imala vraga pa namakla prase. (Grandma didn't have a devil, so she got a pig.), Tko o čemu baba o uštipcima. (Who ever [talks] about anything, grandma [talks] about donuts.)), babica (Mnogo babica kilavo dijete. (Many midwives, ungainly child.)), djevojka (Tko prije djevojci, njegova (je) djevojka. (Who (comes) to the girl first, his (is) the girl.)), kovač (Svatko je (sam) kovač svoje sreće. (Everyone (himself) is a blacksmith of his happiness.)), majka $i$ žena (Daj mi Bože što mi misli žena, ne daj što mi misli majka. (Give me, God, what my wife thinks, don't give me what my mother thinks.)). RHJ includes only four proverbs under the headwords baba (Što je babi milo, to joj se i snilo (What grandma likes, she dreamed of it.)), babica (Što više babica, kilavije dijete (The more midwives, the ungainlier the child.)), djevojka (Tko prije djevojci, njegova djevojka. (Who [comes] to the girl first, his [is] the girl.)) and kovač (Svatko je kovač svoje sreće. (Everyone is a blacksmith of his own happiness.)). There are no proverbs in ŠRHJ.

In contemporary Croatian lexicographic sources, proverbs are also included in online Kolokacijska baza hrvatskoga jezika (Croatian Collocation Database ${ }^{10}$ of the Institute of Croatian Language and Linguistics and they are marked with the label P (proverb). At the moment, 531 entry in the Database is labeled as P. Since each proverb is entered under each word included in the proverb, they are multiplied, leaving 123 original proverbs in total. Figure 1 shows the proverbs under the headword žena (woman) in the Database. Under the entry denoting male and female, there are 25 proverbs žena (7 proverbs), baba (4),

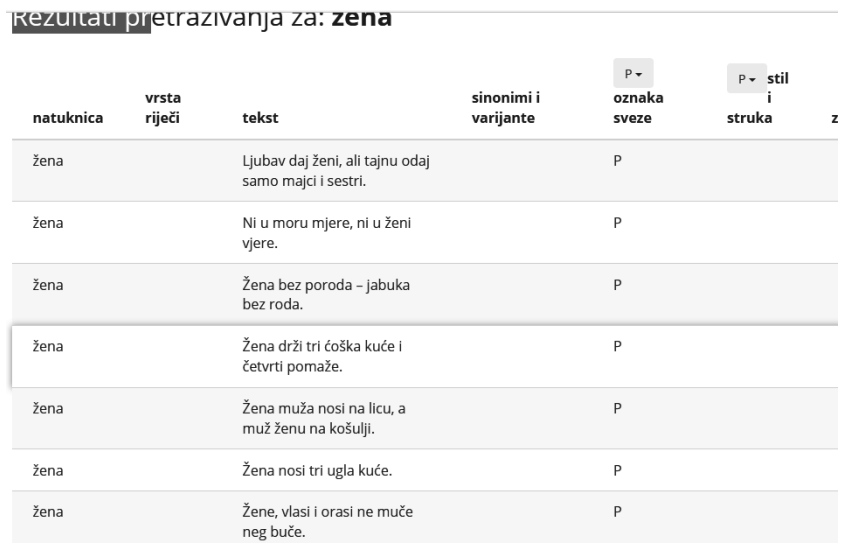

Fig. 1. Proverbs under the headword žena (wife/woman) in Croatian Collocation Database. 
sin (4), otac (2), kći (2), sestra (1), djevojka (1), cura (1), udovica (1), majka (1), muž (1).

\section{Methods: Material and Corpora}

The main goal of this research is to compare proverbs containing nouns denoting male and female in printed collections of proverbs ${ }^{3-6}$ and online Croatian Collocation Database $^{10}$, with proverbs in contemporary corpora of Croatian: Hrvatski mrežni korpus (Croatian web corpus, from now on: $\mathrm{hrWaC})^{11}$ and Hrvatska jezična riznica (Croatian Language Repository, from now on: Riznica $)^{12}$. The analysis includes about twenty nouns that are the main components of proverbs on the topic of male or female: Adam (Adam), baba (grandma), babica (midwife), brat (brother), cura (girl), čovjek (man), dijete (child), djevica (virgin), djevojka (girlfriend), gospodar (master), gospodarica (mistress), kći (daughter), majka (mother), muž (husband), nevjesta (bride), otac (father), sestra (sister), sin (son), sluga (servant), svekrva (mother-in-law), udovica (widow), žena (woman/wife) and nouns denoting male or female occupations: kovač (blacksmith), liječnik (doctor), misnik (priest); čobanica (shepherdess), ribarica (fisherwoman)... In printed sources, around 200 proverbs on male and female were singled out, and then it was searched how many proverbs were confirmed in hrWaC and Riznica. 32 proverbs were found in the corpora ( $\approx 16 \%$ of the total number) in their original form or modified i.e., paraphrased. Considering the data searchable in hrWaC (newspapers, forums, and blogs, as well as official pages and administrative texts) and Riznica (newspapers and Croatian literary sources), the assumption was that more proverbs would be confirmed in the Riznica than in hrWaC. Still, the results showed that they are more frequent in $\mathrm{hrWaC}$, as shown in Table 1. This is probably due to the size of corpora, since Riznica has approximately 85 million tokens, and hrWaC has about 1,9 billion tokens.

\section{Results}

The results of comparing proverbs from printed sources and proverbs from hrWaC and Riznica are shown below. The analysis includes the social context of proverbs, linguistic analysis (structural and semantic features of proverbs on the topic of male and female), comparison of proverbs in printed and corpus sources.

\section{Society, gender and time in proverbs}

The low number of proverbs in the corpora is an indicator of the change in the extralinguistic context i.e., social perception that prevails in proverbs and social perception today. The earliest proverbs ${ }^{3}$ are derived from religious texts (Bible, Koran) and from numerous ancient works and sayings of writers, philosophers, rulers, military leaders of that time. Many proverbs originated in the Middle Ages. For centuries they were spread by word of mouth among the people, having an educational role following the understanding of the position of men and women in the society of that time, which primarily stemmed from patriarchal relations in which gender roles are clearly divided ${ }^{13,14}$. According to gender roles, in the proverbs it is possible to determine quite clearly: 1 the position of women and men in society, family or marriage, 2 characterizations of women and men (as positive and negative), 3 physical appearances of men and women, 4 images of men and women according to age (old age and youth). Al-

TABLE 1

PROVERBS IN PRINTED FORM AND IN CORPORA

\begin{tabular}{|c|c|c|c|}
\hline $\begin{array}{l}\text { Proverbs from printed } \\
\text { sources }\end{array}$ & $\begin{array}{c}\text { Number of } \\
\text { appearances in } \\
\text { hrWaC* }\end{array}$ & $\begin{array}{c}\text { Number of } \\
\text { appearances in } \\
\text { Hrvatska jezična } \\
\text { riznica }^{* *}\end{array}$ & $\begin{array}{l}\text { Proverbs and number of appearances in hrWaC and Hrvatska } \\
\text { jezična riznica*** }\end{array}$ \\
\hline $\begin{array}{l}\text { Ako smo braća, kese nam } \\
\text { nisu sestre. }\end{array}$ & 3 & - & - \\
\hline $\begin{array}{l}\text { Babi se snilo, što joj je } \\
\text { milo. }\end{array}$ & 1 & - & - \\
\hline $\begin{array}{l}\text { Čiji je konj brži, toga je i } \\
\text { djevojka. }\end{array}$ & - & - & $\begin{array}{l}\text { - Tko prvi, njemu djevojka / njegova djevojka. hrWaC: } 5 \\
\text {. Riznica: } 3 \text { (Vjesnik online and Joža Horvat Mačak pod šljemom) }\end{array}$ \\
\hline $\begin{array}{l}\text { Dok dijete ne zaplače, } \\
\text { mati ga se ne sjeća. }\end{array}$ & - & - & . Dok dijete ne zaplače majka mu sise ne daje. hrWaC: 1 \\
\hline $\begin{array}{l}\text { Gdje je mnogo babica, } \\
\text { kilava su djeca. }\end{array}$ & 11 & - & $\begin{array}{l}\text { - Gdje je puno baba kilava su djeca. hrWaC: } 2 \\
\text { - Puno babica(,) kilavo dijete. hrWaC: } 1 \\
\text { - Riznica: } 1 \text { (Vjesnik online) } \\
\text { - Puno baba(,) kilavo dijete. hrWaC: } 15 \\
\text { - Puno baba(,) kilavo je dijete. hrWaC: } 3 \\
\text { - Puno baba kilava su djeca. hrWaC: } 2 \\
\text { - Puno baba (,/a/-) kilavo dite. hrWaC: } 18 \\
\text { - Puno baba kilava dica. hrWaC: } 2\end{array}$ \\
\hline
\end{tabular}


TABLE 1

CONTINUED

\begin{tabular}{|c|c|c|c|}
\hline $\begin{array}{l}\text { Proverbs from printed } \\
\text { sources }\end{array}$ & $\begin{array}{l}\text { Number of } \\
\text { appearances in } \\
\text { hrWaC* }\end{array}$ & $\begin{array}{c}\text { Number of } \\
\text { appearances in } \\
\text { Hrvatska jezična } \\
\text { riznica** }\end{array}$ & $\begin{array}{l}\text { Proverbs and number of appearances in } \mathrm{hrWaC} \text { and Hrvatska } \\
\text { jezična riznica*** }\end{array}$ \\
\hline \multirow{2}{*}{$\begin{array}{l}\text { Jedan sluga ne može } \\
\text { dvoriti dva gospodara. }\end{array}$} & \multirow[t]{2}{*}{1} & \multirow[t]{2}{*}{-} & . Ne može jedan sluga služiti dva gospodara. hrWaC: 1 \\
\hline & & & $\begin{array}{l}\text { Nijedan / Ni jedan sluga ne može služiti dvojici gospodara. } \\
\text { hrWaC: } 6\end{array}$ \\
\hline $\begin{array}{l}\text { Kad je rat, niko nikom } \\
\text { nije brat. }\end{array}$ & - & 1 (Vjesnik online) & Rat nikom/nikome nije brat. hrWaC: 6 \\
\hline \multirow[t]{2}{*}{$\begin{array}{l}\text { Kakav gospodar, takav je } \\
\text { sluga. }\end{array}$} & \multirow[t]{2}{*}{1} & \multirow[t]{2}{*}{-} & $\begin{array}{l}\text { Kakav gospodar, takav pas. } \\
\text { hrWaC: } 2\end{array}$ \\
\hline & & & $\begin{array}{l}\text { Kakav gospodar, takav i sluga. } \\
\text { hrWaC: } 1\end{array}$ \\
\hline \multirow[t]{6}{*}{ Kakav otac takav sin. } & \multirow[t]{6}{*}{83} & \multirow[t]{6}{*}{5} & Kakav otac, takav i sin. \\
\hline & & & hrWaC: 4 \\
\hline & & & Kakav otac, takvi i sinovi. hrWaC: 1 \\
\hline & & & Kakav tata, takav i sin. hrWaC: 1 \\
\hline & & & Kakav ćaća, takav i sin. hrWaC: 1 \\
\hline & & & Kakav otac, takva kći/kćer. hrWaC: 6 \\
\hline Kakav otac taki sin. & - & - & Kakav otac, taki i sin. hrWaC: 1 \\
\hline \multirow[t]{7}{*}{$\begin{array}{l}\text { Kakva mati, takva kči; } \\
\text { kako joča, takov sin. }\end{array}$} & \multirow[t]{7}{*}{-} & \multirow[t]{7}{*}{-} & $\begin{array}{l}\text { Kakav otac - takav sin, kakva majka/mati/mater -takva kći. } \\
\text { hrWaC: } 6\end{array}$ \\
\hline & & & Kakva mati(,) takva kći. \\
\hline & & & · Riznica: 1 (Jeruzalemska Biblija), hrWaC: 2 \\
\hline & & & Kakva majka(,) takva kći. hrWaC: 13 \\
\hline & & & Kakva mama(,) takva kći/kćer. \\
\hline & & & hrWaC: 12 \\
\hline & & & Kakva mater, takva kći. hrWaC: 1 \\
\hline $\begin{array}{l}\text { Knjiga veli da svi ljudi } \\
\text { dolaze od Adama. }\end{array}$ & - & - & - Knjiga veli da svi ljudi dolaze od Adama i Eve. hrWaC: 1 \\
\hline $\begin{array}{l}\text { Komu je otac bog, lako } \\
\text { mu je biti svetac. }\end{array}$ & - & - & - Lako je biti svetac kad ti je Bog otac. hrWaC: 2 \\
\hline $\begin{array}{l}\text { Liječnik liječi, a Bog } \\
\text { ozdravlja. }\end{array}$ & - & $\begin{array}{l}1 \text { (Eugen Kumičić } \\
\text { Urota Zrinsko- } \\
\text { Frankopanska) }\end{array}$ & - \\
\hline $\begin{array}{l}\text { Lijepa je žena rijetko } \\
\text { poštena. }\end{array}$ & 1 & - & - \\
\hline \multirow{2}{*}{$\begin{array}{l}\text { Mlada kurba, stara } \\
\text { prosjakinja. }\end{array}$} & \multirow[t]{2}{*}{-} & \multirow[t]{2}{*}{-} & - Mlada flundra, stara prosjakinja. hrWaC: 1 \\
\hline & & & Mlada curva, stara prosjakinja. hrWaC: 1 \\
\hline \multirow{3}{*}{$\begin{array}{l}\text { Neznanost je majka } \\
\text { nevolje. (majka u } \\
\text { prenesenom značenju) }\end{array}$} & \multirow[t]{3}{*}{-} & \multirow[t]{3}{*}{-} & Neznanje ja majka svih zala. \\
\hline & & & hrWaC: 11; Riznica 1 potvrda \\
\hline & & & Neznanje je majka svih grešaka. hrWaC: 1 \\
\hline $\begin{array}{l}\text { Nije prijatelja do oca i } \\
\text { majke. }\end{array}$ & - & - & $\begin{array}{l}\text { Nemaš ti boljeg druga do oca i majke tvoje. Riznica: } 1 \text { (Živko } \\
\text { Bertić. Ženski udesi.) }\end{array}$ \\
\hline \multirow{2}{*}{$\begin{array}{l}\text { Ponavljanje je majka } \\
\text { nauke. (majka u } \\
\text { prenesenom značenju) }\end{array}$} & \multirow[t]{2}{*}{-} & \multirow[t]{2}{*}{-} & Ponavljanje je majka mudrosti. hrWaC: 42 \\
\hline & & & Ponavljanje je majka znanja. hrWaC: 94 \\
\hline $\begin{array}{l}\text { Puška i žena, dvi virne } \\
\text { drugarice, ne daju se u } \\
\text { tuje ruke. }\end{array}$ & - & - & . Puška i žena se ne daju nikom. hrWaC: 1 \\
\hline Složna braća kuću grade. & 27 & - & - \\
\hline \multirow{2}{*}{$\begin{array}{l}\text { Stara koka mastna čorba. } \\
\text { (preneseno značenje) }\end{array}$} & \multirow[t]{2}{*}{-} & \multirow[t]{2}{*}{-} & Stara koka dobra juha. hrWaC: 11 \\
\hline & & & Stara koka masna juha. hrWaC: 1 \\
\hline $\begin{array}{l}\text { Što se babi htilo, to se } \\
\text { babi snilo. }\end{array}$ & 65 & 1 (Vjesnik online) & - \\
\hline \multirow{2}{*}{$\begin{array}{l}\text { Teško majci benu } \\
\text { rađajući, a kraljevstvu } \\
\text { dijete vladajući. }\end{array}$} & \multirow[t]{2}{*}{-} & \multirow[t]{2}{*}{-} & · Teško majci budalu rodeći, a kraljevstvu dite vladajući! \\
\hline & & & $\begin{array}{l}\text { - Riznica: } 1 \text { (Andrija Kačić Miošić, Razgovor ugodni naroda } \\
\text { slovinskoga) }\end{array}$ \\
\hline
\end{tabular}


TABLE 1

CONTINUED

\begin{tabular}{|c|c|c|c|}
\hline $\begin{array}{l}\text { Proverbs from printed } \\
\text { sources }\end{array}$ & $\begin{array}{l}\text { Number of } \\
\text { appearances in } \\
\text { hrWaC* }\end{array}$ & $\begin{array}{l}\text { Number of } \\
\text { appearances in } \\
\text { Hrvatska jezična } \\
\text { riznica }\end{array}$ & $\begin{array}{l}\text { Proverbs and number of appearances in } \mathrm{hrWaC} \text { and Hrvatska } \\
\text { jezična riznica*** }\end{array}$ \\
\hline $\begin{array}{l}\text { Tko Bogu služi, ima } \\
\text { dobra gospodara. }\end{array}$ & - & - & . Tko Bogu služi, taj ne ubija nikoga. hrWaC: 1 \\
\hline $\begin{array}{l}\text { Tko nije kuću gradio i } \\
\text { kćer udavao, ne zna što je } \\
\text { trošak. }\end{array}$ & 1 & - & - U dobra gospodara, dobar i sluga. hrWaC: 1 \\
\hline $\begin{array}{l}\text { U radiše svega biše, u } \\
\text { štediše i još više. }\end{array}$ & 17 & 1 & $\begin{array}{l}\text { U radiše malo biše, u štediše ništa više. Riznica: } 1 \text { (Vjesnik } \\
\text { online) } \\
\text {. U štediše svega biše, u radiše i još / još i više. hrWaC: } 2\end{array}$ \\
\hline Vjeran sluga je kao brat. & - & - & $\begin{array}{l}\text { Vjeran sluga ne pita / nepita, već sluša. Riznica: } 2 \text { (Šenoa: } \\
\text { Sabrane pripoviesti and Seljačka buna) }\end{array}$ \\
\hline $\begin{array}{l}\text { Žena kuću drži. / Žena } \\
\text { drži tri ugla kuće, a muž } \\
\text { jedan. }\end{array}$ & - & - & $\begin{array}{l}\text { Žena drži } 3 \text { kantuna kuće, muž samo jedan. hrWaC } 1 \\
\text {. Žena drži tri/3 kantuna kuće. hrWaC: } 7 \\
\text {. Žena drži tri ćoška kuće. hrWaC: } 3 \\
\text {. Žena drži tri kantuna od kuće. hrWaC: } 2 \\
\text {. Žena drži 3/tri od 4/četiri kanutna kuće. hrWaC: } 2 \\
\text {. Žena drži tri zida kuće. hrWaC: } 2 \\
\text {. Žena drži sva } 4 \text { ugla. hrWaC: } 1 \\
\text {. Žena drži sva } 4 \text { kantuna kuće. hrWaC: } 1 \\
\text {. Žena drži tri ćoška u kući. hrWaC: } 1 \\
\text {. Žena drži tri ugla u kući. hrWaC: } 1 \\
\text {. Žena drži tri kuta u kući. hrWaC: } 1 \\
\text {. Žena drži tri, a muškarac tek četvrti kantun u kući. hrWaC: } 1\end{array}$ \\
\hline $\begin{array}{l}\text { Ženi se od kuće, pa } \\
\text { makar od kučke. (kučka } \\
\text { pogrdno preneseno zn. za } \\
\text { pokvarenu ženu.) }\end{array}$ & - & - & $\begin{array}{l}\text { Ženi se od kuće (ugledne), da je gora od kučke nadoći će. } \\
\text { hrWaC:1 }\end{array}$ \\
\hline
\end{tabular}

though such gender relationships have not completely disappeared, proverbs in modern times (late $20^{\text {th }}$ and $21^{\text {st }}$ centuries) lose on topicality concerning the messages they contain. Such a status of proverbs is conditioned by the fact that male and female roles and perceptions of social values have changed or are changing, and based on that, it is possible to conclude that universality and timelessness is not a feature that can be attributed to all proverbs. According to the corpus results on male-female relations, proverbs with general meaning that can be applied to broader social contexts were confirmed: Mnogo/Puno babica, kilavo dijete. (Many midwives, ungainly child.) - a proverb refers to situations where many helpers bring poor results; Kakav otac, takav sin. (Like father, like son.), Kakva majka, takva kcii. (Like mother, like daughter.) - proverbs referring to the character or physical similarity of parents and children; Staroj mačci mlad mišić. (To the old cat, young mouse.) - a proverb referring to the relationship between an older woman and a younger man. Also, nowadays, proverbs are suppressed by slogans - modern short forms that promote the idea of a social or political group, commercial brand or service. Slogans contain messages of contemporary society that are close and understandable to today's speakers of a community (e.g., Čistoća je pola $z$ dravlja. (Cleanliness is half of the health.), Bolje spriječiti nego liječiti. (Better to prevent than to treat.), Vrijeme je novac. (Time is money.), Čist račun, duga ljubav. (Clean account, long love.)). The role of proverbs is also suppressed by popular culture (movies, songs, books, etc.) because one sentence or verse can become popular, outside the framework of the media in which they originated, which is the subject of independent research.

\section{Linguistic analysis of proverbs}

At the linguistic level, the structural and semantic features of proverbs are analyzed. Although each carries a special message, proverbs have general, i.e., standard features that make them a recognizable short form. According to the structure, proverbs from printed sources were com- 
pared with proverbs from mentioned online corpora, including their lexical and syntactic differences. Regarding the research topic, proverbs are grouped according to their semantic features, which refer to different male-female relationships and the social status of men and women.

\section{Typical syntactic structures in proverbs}

Among the examined proverbs, three main structures prevail, which represent the content of the proverb with a limited number of words, concisely and rhythmically. In the background of such structures is primarily the oral medium - proverbs were transmitted by word of mouth, they were listened to and they were supposed to be easily remembered through content that is close to the experience of the community in which they are transmitted:

-Multiple subjects/objects: most often, a woman is associated with other concepts e.g., objects, plants or animals: Ženu, pušku i konja može čovjek pokazati, ali u naruč ne davati. (A man can show a woman, a rifle and a horse, but he must not give them in others arms.), Ženu, djecu $i$ psa treba biti i hraniti. (A woman, children, and a dog should be beaten and fed.), U ženi $i$ u mački ne imaj vjere. (Do not have faith in a woman and a cat.), Trud $i$ učenje - brat $i$ sestra. (Work and learning - brother and sister.), Puška i žena, dvi virne drugarice, ne daju se u tuje ruke. (The rifle and the woman, two faithful friends, are not to be given in someone else's hands.), Djevice i lubenice trudno je poznati. (Virgins and watermelons are hard to know.), Umiljati otac $i$ umiljata majka slabu dicu goje. (The cuddly father and the cuddly mother raise weak children.), Žene, vlasi i orasi ne muče neg buče. (Women, Vlachs, and walnuts do not keep silent but make a noise.).

-Syntactic parallelism: a proverb contains two contents related to each other: Kakva mati, takva kći, kakav otac takav sin. (Like mother, like daughter, like father, like son.), Žena bez poroda-jabuka bez roda. (A woman without childbirth - an apple without a fruit.), Duge kose, kratka pamet. (Long hair, short wit.), Stara koka, masna/dobra juha. (Old hen, greasy/good soup), Teško majci benu rađajući, a kraljevstuu dijete vladajucii. (It is challenging both for a mother to give birth to a crazy child, and for a kingdom when a child rules.), Trud $i$ učenje - brat $i$ sestra. (Work and learning - brother and sister.), Djevojačka pamet, rosa na listu. (Girl's wit, dew on the leaf.), Ženske suze, mačji kašalj. (Women's tears, cat's cough.), Kakvo gnizdo, takva tica, kakav kotac, takva dica. (Like a nest, like a bird, like father, like children.), Teško zemlji bez težaka, ribi bez vode, a ženi bez čovika. (It is difficult for the land without a farmer, for a fish without a water, and for a woman without a man.), Ni u moru mjere, ni u ženi vjere. (Neither the sea has the measure/size, nor the woman has the faith.), Zemlja za težaka, sablja za junaka, a pero $z a$ gospodina. (A land for a farmer, a sword for a hero, and a feather for a gentleman.), Kakva mati, takva kči; kako joča, takov sin. (Like mother, like daughter; like father, like son.), Kakav otac, taki sin. (Like fa- ther, like son.), Kakvo drvo, takav klin, kakav otac, takav sin. (Like tree, like wedge, like father, like son.), Mat ni žena dok nema hćere, otac ni muž dok nema sina. (A mother is not a wife without a daughter, a father is not a husband without a son.).

- Comparative proverbs: two contents are compared with a conjunction kaolkako (as/like): Pjanac je kako $i$ žena ka, kad jednu votu čas' izgubi, veće ju nigda ne steče. (A drunkard is like a woman who, once she loses a good reputation, never gains it again.), S ženama valja kako s mazgom: neće - a ti udri. (Women should be treated like a mule: if she doesn't want to - you hit.), Udovica je ka drvo posičeno. (A widow is like a cut tree.).

\section{Differences between printed sources and corpora}

Among the 32 proverbs confirmed in corpora on the topic of male, some proverbs are recorded in their original (as in printed). Still most proverbs from corpora differ in some components from the original form. The differences include changes in the syntactic and/or lexical structure of the proverb. The most common changes at the syntactic level are in the word order (e.g., printed form: Komu je otac bog, lako mu je biti svetac. (To whom the father is a god, it is easy for him to be a saint) $\rightarrow$ corpus: Lako je biti svetac kad ti je Bog otac. (It is easy to be a saint when God is your father.)); in sentence type (e.g., printed form (compound sentence): Kad je rat, niko nikom nije brat. (When there is a war, no one is a brother to anyone.) $\rightarrow$ corpus (simple sentence): Rat nikom nije brat. (War is no brother to anyone.)); in sentence composition (e.g., printed form (with predicate): Gdje je mnogo babica, kilava su djeca. (Where there are many midwives, children are ungainly.) $\rightarrow$ corpus (without predicate): Puno babica, kilavo dijete. (Lots of midwives, clumsy child.)).

Changes at the lexical level suggest that some lexemes in proverbs from corpora are different from proverbs in printed form. Such changes in vocabulary point to changes in social and communication habits in the past and today, but it can also be assumed that proverbs in the corpora have changed under the influence of authorial editing and conscious intervention in language. E.g., in printed proverb Jedan sluga ne može dvoriti dva gospodara. (One servant can't serve two masters.) a more stylistically (regional and literary) marked verb dvoriti (serve) appears. In corpora a proverb containing the verb služiti (serve) is confirmed: Ne može jedan sluga služiti dva gospodara. (lit. Can't one servant serve two masters.). In printed proverbs for the male parent, only the noun otac (father) appears, e.g., Kakav otac, takav sin. (Like father, like son.), and in the proverbs in the corpora, the informal form tata (dad) and the regional form ćaća are confirmed. (Kakav tata, takav i sin. / Kakav ćaća, takav i sin.). Certainly, an interesting proverb is Kakav gospodar, takav je sluga. (Like master like servant.), which is confirmed in corpora in the form Kakav gospodar, takav pas (Like master like dog.), referring to today's more common relationship between the owner and the dog than the master and the servant. Table 2 lists all lexical differences between 
proverbs in printed form and proverbs confirmed in corpora (hrWaC and Riznica). Differences include lexemes denoting male and female, but also other components.

Some proverbs in corpora differ according to phonetic features, which result in stylistic features, i.e. the relationship between the archaic or regional form in the printed source (e.g., in the proverb Kakva mati, takva kči; kako joča, takov sin (Like mother, like daughter, like father, like son) there is regional form joča for Croatian noun otac (father), and regional form takov for Croatian pronoun/ predeterminer takav (such)).

\section{Analysis of nouns denoting male and female in proverbs}

The analysis of male and female components in proverbs is primarily based on social categories (work, marriage, parent-child communication, customs) and value categories (morality, honesty, knowledge, wisdom, kindness, physical appearance). Within these categories women and men are most often polarized as positive or negative, as shown in Table 3 on selection of proverbs from our corpus, with the woman having a more negative status than the man, which coincides with the already described position of women in Croatian proverbs and other folk forms. ${ }^{15}$ It is on such polarization that the gender image of man and woman in proverbs is created. ${ }^{16}$ The negative or positive image of a woman and a man in proverbs includes their appearance, their character, and the position of member of one gender in relation to member of another gender. However, it should be noted that not all of them are exclusively negative, but some of them present a positive image of a woman as a person or speak positively about the harmony between a man and a woman, which will be shown below. Analyzing individual components, some of the nouns denoting male or female come more often than the others. The most commonly used noun in analyzed proverbs is žena (recorded almost 70 times), which appears in two senses - as an adult female: Lijepa je žena rijetko poštena. (A beautiful woman is rarely honest.), Tri žene, jedna guska, čine vašar. (Three women, one goose, they make a fair); or as a married woman in relation to the husband she is married to, which appears in proverbs Žena drži tri ugla kuće, a muž jedan. (The wife

TABLE 2

DIFFERENCES BETWEEN PROVERBS IN PRINTED SOURCES AND IN CORPORA

\begin{tabular}{|c|c|c|}
\hline Proverb in printed source & Proverb in corpus source & Type of difference \\
\hline Čiji je konj brži, toga je i djevojka. & Tko prvi, njemu djevojka / njegova djevojka. & $\begin{array}{c}\text { lexical } \\
\text { syntactic }\end{array}$ \\
\hline Dok dijete ne zaplače, mati ga se ne sjeća. & Dok dijete ne zaplače majka mu sise ne daje. & lexical \\
\hline Gdje je mnogo babica, kilava su djeca. & $\begin{array}{l}\text { Puno babica(,) kilavo dijete. } \\
\text { Puno baba, kilavo dijete. Puno baba kilava su djeca. Puno baba } \\
\text { (,/a/-) kilavo dite. } \\
\text { Puno baba kilava dica. }\end{array}$ & lexical \\
\hline $\begin{array}{l}\text { Jedan sluga ne može dvoriti dva gospo- } \\
\text { dara. }\end{array}$ & $\begin{array}{l}\text { Ne može jedan sluga služiti dva gospodara. } \\
\text { Nijedan / Ni jedan sluga ne može služiti dvojici gospodara. }\end{array}$ & $\begin{array}{c}\text { lexical } \\
\text { symtactic }\end{array}$ \\
\hline Kakav gospodar, takav je sluga. & $\begin{array}{l}\text { Kakav gospodar, takav i sluga. } \\
\text { Kakav gospodar, takav pas. }\end{array}$ & $\begin{array}{c}\text { lexical } \\
\text { syntactic }\end{array}$ \\
\hline Kad je rat, niko nikom nije brat. & Rat nikom/nikome nije brat. & syntactic \\
\hline Kakav otac takav sin. & $\begin{array}{l}\text { Kakav otac, takav i sin. Kakav otac, takvi i sinovi. Kakav tata, } \\
\text { takav i sin. Kakav ćaća, takav i sin. Kakav otac, takva kći/kćer. } \\
\text { (leksemi: otac : tata, ćaća, kći) tata i ćaća (stilsko (razgovorno) i } \\
\text { regionalno). }\end{array}$ & lexical \\
\hline $\begin{array}{l}\text { Kakva mati, takva kči; kako joča, takov } \\
\text { sin. }\end{array}$ & $\begin{array}{l}\text { Kakav otac - takav sin, kakva majka/mati/mater - takva kći. } \\
\text { Kakva mati(,) takva kći. Kakva majka(,) takva kći. Kakva } \\
\text { mama(,) takva kći/kćer. } \\
\text { Kakva mater, takva kći. }\end{array}$ & $\begin{array}{c}\text { lexical } \\
\text { phonetic }\end{array}$ \\
\hline Komu je otac bog, lako mu je biti svetac. & Lako je biti svetac kad ti je Bog otac. & syntactic \\
\hline Mlada kurba, stara prosjakinja. & Mlada flundra, stara prosjakinja. & lexical \\
\hline Neznanost je majka nevolje. & $\begin{array}{l}\text { Neznanje ja majka svih zala. Neznanje je majka svih grešaka. } \\
\text { (tvorbena i leksička promjena }\end{array}$ & lexical \\
\hline Nije prijatelja do oca i majke. & Nemaš ti boljeg druga do oca i majke tvoje. (leksička i sintaktička) & $\begin{array}{c}\text { lexical } \\
\text { syntactic }\end{array}$ \\
\hline
\end{tabular}


TABLE 2

CONTINUED

\begin{tabular}{|c|c|c|}
\hline Proverb in printed source & Proverb in corpus source & Type of difference \\
\hline Ponavljanje je majka nauke. & $\begin{array}{l}\text { Ponavljanje je majka mudrosti. } \\
\text { Ponavljanje je majka znanja. }\end{array}$ & lexical \\
\hline $\begin{array}{l}\text { Puška i žena, dvi virne drugarice, ne daju } \\
\text { se u tuje ruke. }\end{array}$ & Puška i žena se ne daju nikom. & $\begin{array}{l}\text { lexical } \\
\text { syntactic } \\
\text { stylistic }\end{array}$ \\
\hline Stara koka mastna čorba. & $\begin{array}{l}\text { Stara koka dobra juha. } \\
\text { Stara koka masna juha. (leksička, ortografska) } \\
\text { Teško majci benu rađajući, a kraljevstvu dijete vladajući. Teško } \\
\text { majci budalu rodeći, a kraljevstvu dite vladajući! }\end{array}$ & $\begin{array}{l}\text { lexical } \\
\text { phonetic } \\
\text { stylistic }\end{array}$ \\
\hline U radiše svega biše, u štediše i još više. & $\begin{array}{l}\text { U radiše malo biše, u štediše ništa više. } \\
\text { U štediše svega biše, u radiše i još / još i više. }\end{array}$ & lexical \\
\hline Vjeran sluga je kao brat. & Vjeran sluga ne pita / nepita, već sluša. & $\begin{array}{c}\text { lexical } \\
\text { syntactic }\end{array}$ \\
\hline $\begin{array}{l}\text { Žena kuću drži. } \\
\text { Žena drži tri ugla kuće, a muž jedan. }\end{array}$ & $\begin{array}{l}\text { Žena drži } 3 \text { kantuna kuće, muž samo jedan. } \\
\text { Žena drži tri/3 kantuna kuće. Žena drži tri ćoška kuće. Žena drži } \\
\text { tri kantuna od kuće. } \\
\text { Žena drži } 3 / \text { tri od 4/četiri kanutna kuće. } \\
\text { Žena drži tri zida kuće. Žena drži sva } 4 \text { ugla. } \\
\text { Žena drži sva } 4 \text { kantuna kuće. } \\
\text { Žena drži tri ćoška u kući. Žena drži tri ugla u kući. } \\
\text { Žena drži tri kuta u kući. Žena drži tri, a muškarac tek četvrti } \\
\text { kantun u kući. }\end{array}$ & $\begin{array}{c}\text { lexical } \\
\text { syntactic }\end{array}$ \\
\hline
\end{tabular}

holds three corners of the house, and the husband one.), Žena koja miraz donese vlada mužem. (A woman who brings a dowry rules the husband.).

The family is the core of the society, the basic social unit, whose members are close blood relatives, and relationships in the family and its members are a frequent topic of proverbs. The mother is most often mentioned, but very often proverbs talk about the father, the son, the daughter, and members of the extended family: motherin-law, daughter-in-law.

Nouns majka or mati (mother) are the second most common nouns appearing in proverbs, and the mother as a female parent is usually the embodiment of some positive trait, protector or concerned person: Nad sunašce ni svitlosti, a nad majku ni milosti. (Above the sun there is no light, and above the mother there is no mercy.). In some proverbs, the mother appears in the figurative sense of origin: Laž je majka prevare. (A lie is the mother of deception.), Ponavljanje je majka nauke. (Repetition is the mother of knowledge.). What comes from the mother can be negative, like prijevara (deception), neznanje (ignorance), drskost (insolence), but it can also be positive, like knowledge. The father appears in a small number of proverbs (around 15 time), mainly in the meaning of a male parent: U stara otca sirotna djeca (In an old father orphaned children.), Umiljati otac i umiljata majka slabu dicu goje. (The cuddly father and the cuddly mother raise weak children.). In some proverbs, the father and the mother appear: Bolje je oca ženit negli mater udavat. (It is better to marry a father than to marry a mother). The prevalence of mother mentioned in proverbs confirms the importance of the mother's role in the life and upbringing of children.

Kći (daughter) and sin (son) usually come in the context of marriage, for example, in the same proverb: Ženi sina kad hoćeš, a kćer kad možeš. (Marry a son when you want and a daughter when you can.). In proverbs, the daughter is usually seen as a burden: Tko nije kuću gradio $i$ kćer udavao, ne zna što je trošak. (He who has not built a house and married a daughter, does not know what the cost is.), while for the son, there is a choice and the proverbs with son are often a piece of advice on how to marry a son well: Sadi lozu iz temelja, ženi sina iz plemena. (Plant a vine from the foundation, marry a son from a tribe.). The daughter is usually associated with the mother and the father with the son: Kakva mati, takva kči; kako joča, takov sin. (Like mother, like daughter, like father, like son.).

Although dijete (child) does not have expressed gender, it often comes with some noun denoting male or female: Gdje je mnogo babica, kilava su djeca. (Where there are many midwives, children are ungainly.), Ženu, djecu i psa treba biti i hraniti. (A woman, children and a dog should be beaten and fed.).

Djevojka (girl) and cura (girl, colloquial) appear in proverbs mainly in the context of marriage: Divojke prokšene hote bit prošene. (Picky girls want to be proposed.), Dobra roba sama se prodaje, a dievojka sama se 
TABLE 3

POSITIVE AND NEGATIVE IMAGE OF FEMALE AND MALE IN PROVERBS ACCORDING TO SOCIAL AND VALUE CATEGORIES

\begin{tabular}{|c|c|c|c|}
\hline Proverb & $\begin{array}{c}\text { Female }(\mathrm{F}) / \\
\text { male }(\mathrm{M})\end{array}$ & $\begin{array}{c}\text { Positive }(\mathrm{P}) / \\
\text { negative }(\mathrm{N}) \text { image }\end{array}$ & Social or value category \\
\hline Lijepa je žena rijetko poštena. & $\mathrm{F}$ & $\mathrm{N}$ & honesty \\
\hline Tri žene, jedna guska, čine vašar. & $\mathrm{F}$ & $\mathrm{N}$ & talkativeness \\
\hline Bolje je oca ženit negli mater udavat. & $\begin{array}{c}\mathrm{M} \\
\mathrm{F}\end{array}$ & $\begin{array}{l}\mathrm{P} \\
\mathrm{N}\end{array}$ & marriage \\
\hline Tko nije kuću gradio i kćer udavao, ne zna što je trošak. & $\mathrm{F}$ & $\mathrm{N}$ & marriage, expense \\
\hline Ženi sina kad hoćeš, a kćer kad možeš. & $\begin{array}{l}\mathrm{M} \\
\mathrm{F}\end{array}$ & $\begin{array}{l}\mathrm{P} \\
\mathrm{N}\end{array}$ & marriage \\
\hline Ženu, djecu i psa treba biti i hraniti. & $\mathrm{F}$ & $\mathrm{N}$ & man domination \\
\hline Žena drži tri ugla kuće, a muž jedan. & $\begin{array}{l}\mathrm{F} \\
\mathrm{M}\end{array}$ & $\begin{array}{l}\mathrm{P} \\
\mathrm{N}\end{array}$ & organization of home life \\
\hline Žena koja miraz donese vlada mužem. & $\begin{array}{l}\mathrm{F} \\
\mathrm{M}\end{array}$ & $\begin{array}{l}\mathrm{P} \\
\mathrm{N}\end{array}$ & woman domination \\
\hline U stara otca sirotna djeca. & M & $\mathrm{N}$ & old parent \\
\hline Žena bez poroda - jabuka bez roda. & $\mathrm{F}$ & $\mathrm{N}$ & infertility \\
\hline Kakva mati, takva kči; kako joča, takov sin. & $\begin{array}{l}\mathrm{F} \\
\mathrm{M}\end{array}$ & $\begin{array}{l}\mathrm{P} / \mathrm{N} \\
\mathrm{P} / \mathrm{N}\end{array}$ & family resemblence \\
\hline Divojke prokšene hote bit prošene. & $\mathrm{F}$ & $\mathrm{N}$ & vanity \\
\hline Dobra roba sama se prodaje, a dievojka sama se udaje. & $\mathrm{F}$ & $\mathrm{P}$ & marriage \\
\hline Svekrva ni od gnjile nije dobra, a nevjesta ni od gnjile ni od meda. & $\mathrm{F}$ & $\mathrm{N}$ & family relations \\
\hline Bolje je valjan prijatelj, nego rođen brat. & M & $\mathrm{N}$ & family relations \\
\hline Složna braća kuću grade. & M & $\mathrm{P}$ & family relations \\
\hline Udovica je ka' drvo posičeno. & $\mathrm{F}$ & $\mathrm{N}$ & widowhood \\
\hline Mlada kurba, stara prosjakinja. & $\mathrm{F}$ & $\mathrm{N}$ & promiscuity \\
\hline Gori je ženski jezik no turska sablja. & $\mathrm{F}$ & $\mathrm{N}$ & talkativeness \\
\hline Duge kose, a kratku pamet žena imade. & $\mathrm{F}$ & $\mathrm{N}$ & appearance/intelligence \\
\hline Djevojačka pamet, rosa na listu. & $\mathrm{F}$ & $\mathrm{N}$ & Intelligence \\
\hline Ni u moru mjere, ni u ženi vjere. & $\mathrm{F}$ & $\mathrm{N}$ & honesty \\
\hline Dok žena plače, sprema se da prevari. & $\mathrm{F}$ & $\mathrm{N}$ & honesty \\
\hline Žena je i vraga prevarila. & $\mathrm{F}$ & $\mathrm{N}$ & honesty \\
\hline Puška i žena, dvi virne drugarice, ne daju se u tuje ruke. & $\mathrm{F}$ & $\mathrm{N}$ & man domination \\
\hline S ženama valja kako s mazgom: neće - a ti udri. & $\mathrm{F}$ & $\mathrm{N}$ & man domination \\
\hline Ako ženu tučeš, svoju sreću tučeš. & $\mathrm{F}$ & $\mathrm{N}$ & man domination \\
\hline Žena je muka, bez koje se biti ne može. & $\mathrm{F}$ & $\mathrm{N}$ & marriage \\
\hline Dobra žena praznu kuću čini da je puna. & $\mathrm{F}$ & $\mathrm{P}$ & organization of home life \\
\hline Dobre žene ne imaju ni očiju ni ušiju. & $\mathrm{F}$ & $\mathrm{P}$ & $\begin{array}{l}\text { expectation from women: } \\
\text { reliability }\end{array}$ \\
\hline U ženi i u mački ne imaj vjere. & $\mathrm{F}$ & $\mathrm{N}$ & honesty \\
\hline U dobra gospodara, dobar i sluga. & M & $\mathrm{P}$ & social relation \\
\hline Sram divojkam cenu daje. & $\mathrm{F}$ & $\mathrm{P}$ & $\begin{array}{l}\text { expectation from women: } \\
\text { shame }\end{array}$ \\
\hline
\end{tabular}

udaje. (Good goods sell themselves, and a girl marries herself.). In the context of marriage, the virtues expected from the girl, are emphasized: Dobrota u djevojci veće valja neg velika prćija. (Goodness in a girl is more important than a significant dowry.), Lice curu udaje. (The face of a girl marries her.). A girl is a potential bride who wants to get married: Ili je mala nevjesta ili je velika, jednako djevera ište. (Either a little bride or a big one, she is equally looking for a brother-in-law). In the new family, the bride is the daughter-in-law, and the relationship of the daughter-in-law and the mother-in-law is expressed in proverbs: Svekrva ni od gnjile nije dobra, a nevjesta ni od gnjile ni 
od meda. (The mother-in-law is not good from clay, and the bride is not good from clay nor honey.), Svekrva se ne sjeća, da je negda i ona snaha bila. (The mother-in-law does not remember that she was once a daughter-in-law.).

Sestra (sister) comes in just a few proverbs: Sestra udata, susjeda nazvata. (Sister married, a neighbor called.) (which suggests that the sister is no longer a member of the family after she is married) and Ako smo braća, kese nam nisu sestre. (If we are brothers, our bags are not sisters.). On the other hand, brat (brother) is much more represented than a sister, and he has an important function, he is presented in a positive light as in the proverb: Vjeran sluga je kao brat. (A faithful servant is like a brother.) or he is a possible source of the problem to be wary of: Bolje je valjan prijatelj, nego roden brat. (A good friend is better than a born brother.), Brat se u brata poufat ne može. (A brother cannot trust a brother.). This ambivalence is seen in the proverb Složna braća kuću grade. (The harmonious brothers build a house.), which also comes in the extended form Skladna braća nove dvore grade, a neskladna $i$ stare prodaju. (The harmonious brothers build a new court, and the discordant sell the old ones.).

Baba (grandma) regionally means 'mother's mother or father's mother' and, derogatory, 'a woman who is many years old' or 'a female person'. It appears in proverbs: $Z a$ nevolju babu vodu, kad djevojke ne nahodu. (They take grandma for trouble when they can't find a girl.) and Babi se snilo, što joj je milo. (Grandma dreamed, which is pleasing to her.) (with the variation Što se babi htilo, to se babi snilo. / Što se babi htjelo, to se babi snjelo. (What grandma wanted, she dreamed of it.) and Što baba veli, to baba želi. (What grandma says, grandma wants.)).

The status of a widow in the society was not favorable, which can be seen from the negatively connoted proverbs including the noun udovica (widow): Udovica je ka' drvo posičeno. (A widow is like a cut tree.), Udovica, tuda polovica. (Widow, someone else's half.).

Love and marriage as an act of creating a family are topics of proverbs that give advice for a good selection of a partner and ultimately a happy marriage: Iz ljubavi ženidba je prava, za interes prodaje se krava. (Out of love, marriage is real, for interest a cow is sold.), Ženi se na blizu, kumi se na daleko. (Get married close, find a godfather far.).

Nouns denoting occupations are masculine, but this masculine gender can be understood as a general gender, both male and female: Liječnik liječi, a Bog ozdravlja. (The doctor treats, and God heals.), although some occupations are traditionally primarily male: Nije brodar vjetru gospodar. (The shipper is not the master of the wind.), $U$ kovača crne ruke a bijela pogača. (The blacksmith has black hands and white bread.). It is interesting that in some proverbs, some professions also appear in the feminine gender. They characterize the female in some way: Kad je gospodarica lena, nit družina ne valja. (When the mistress is lazy, the family is not good either.), Mlada kurba, stara prosjakinja. (A young whore, an old beggar.).
The female and male world in Croatian proverbs can be analyzed at the level of expression and at the level of content. Proverbs that contain nouns referring to male and/or female do not relate exclusively to male-female relationships and the status of men and women in the family and society. For example, the proverb Babi se snilo, što joj je milo. (What grandma likes, she dreamed of it.) refers to the desire that someone has, not exclusively a grandma, not even a female person. The proverb Najbosija je kovačka kobila $i$ postolarska žena. (The most barefoot is a blacksmith's mare and a shoemaker's wife.) talks about the attitude to work. In the proverb U junaka jadna majka. (The mother of the hero is poor.), the mother's grief is themed, but it actually speaks of heroism paid with life and indirectly gives advice that heroism is not always desirable.

\section{Thematic analysis of proverbs}

Proverbs with male and female nouns depict the world in which they originated, and many stereotypes formed in society come to light. Although many proverbs talk about love, marriage, and relationships in the marriage and family, the number of proverbs with words naming a female person (a woman dominates, but there is also a girl, a grandmother ...) stands out. In them, women are more often described in a negative context than in a positive one. Women are chatty: Gori je ženski jezik no turska sablja. (A female tongue is worse than a Turkish saber.), Težeje žena muči neg dete rodi. (It is harder for a woman to be silent than to give birth.); with no brains: Djevojačka pamet, rosa na listu. (Girl's wit, dew on the leaf.), Duge kose, a kratku pamet žena imade. (Long hair, and short wit a woman has.); unfaithful: Ni u moru mjere, ni u ženi vjere. (Neither the sea has the measure/size, nor the woman has the faith.), $U \check{z}$ eni $i$ u mački ne imaj vjere. (Do not have faith in a woman and a cat.); deceitful: Dok žena plače, sprema se da prevari. (While the woman is crying, she is getting ready to cheat.), Žena je i vraga prevarila. (The woman cheated even on the devil.); picky: A ni na suit još se rodil ki bi ženi vse ugodil. (No one has yet been born in the world to please a woman in everything.), Divojke prokšene hote bit prošene. (Picky girls want to be proposed.). In some proverbs, women are compared to animals and things that can be given, sold and bought: Puška $i$ žena, dvi virne drugarice, ne daju se u tuje ruke. (The rifle and the woman, two faithful friends, are not to be given in someone else's hands.), Ženu i platno ne kupi pri svieći. (Do not buy a woman and a cloth by the candlelight.). It is not uncommon for a woman to be exposed to beatings. The proverb $S$ ženama valja kako s mazgom: neće - a ti udri. (Women should be treated like a mule: if she doesn't want to - you hit.) encourages the beating, but the proverb Ako ženu tučeš, svoju sreću tučeš. (If you beat a woman, you beat your luck.) advises against this treatment. To sum up, although a woman is an evil and a torment, it is still impossible to be without her: Žena je muka, bez koje se biti ne može. (A woman is a torment, without which one cannot exist.), Žena je zlo, bez koga se biti ne može. (A woman is an evil, without which one cannot ex- 
ist.). Given this inevitability, there are many proverbs describing a good woman, perhaps formed as an instruction to women what is expected of them: Dobra žena praznu kuću čini da je puna. (A good woman makes an empty house full.), Dobra žena srcem ljubi, a zla jezikom ujeda. (A good woman loves with her heart, and the evil one bites with her tongue.), Dobre žene ne imaju ni očiju ni ušiju. (Good women have no eyes or ears.). According to proverbs, the woman's place is in the house: $N a$ ženi kuća ostaje. (The house remains on the woman.), Žena $\mathrm{d} r z \check{i}$ tri ugla kuce, a muž jedan. (The wife holds the three corners of the house, and the husband one.).

Marriage as the union of a woman and a man is the basis of a family and the foundation of the Croatian society: Ženidba je sveta, a razženidba prokleta. (Marriage is sacred, and divorce is accursed.). In choosing a partner for marriage, young men and his family have more options: Sadi lozu iz temelja, ženi sina iz plemena. (You should plant a vine from the foundation and marry a son from the tribe.), Ženi sina kad hoćeš, a kćer kad možeš. (Marry a son when you want, and a daughter when you can.). Some proverbs advise on how to choose a suitable bride and which qualities are good for the future everyday life: Ako misliš kćerku dobiti, klanjaj se majki. (If you plan to have a daughter, worship the mother.), Dobrota u djevojci veće valja neg velika prćija. (Goodness in a girl is more important than a significant dowry.), Ženi se na blizu, kumi se na daleko. (Get married close, find a godfather far.). The girl is expected to be chaste and faithful: Junaku oružje, ni ženi odjeća, ne skida se. (The hero's weapon, and his wife's clothes, are not to take off.), Kad je divojka viru dala, kao da se i udala. (When the girl gave her faith, it is as if she got married.), Sram divojkam cenu daje. (Shame gives girls a price.). For girls, marriage is very important: Ili je mala nevjesta ili je velika, jednako djevera ište. (Either a little bride or a big one, she is equally looking for a brother-in-law). For a girl, beauty is an advantage: Lice curu udaje. (The face of a girl marries her.), but it can also be a disadvantage: Lijepa je žena rijetko poštena. (A beautiful woman is seldom honest.), Tko ima lijepu kuću i lijepu ženu, nije gospodar od nje. (He who has a beautiful house and a beautiful wife is not the master of it.). Some proverbs give advice about marriage: Muža ljubi kako prijatelja, a boj ga se kako neprijatelja. (Love your husband as a friend, and fear him as an enemy.), Žena svjetla mužu obraz, a muž ženi ime daje. (The wife lights the husband's cheek, and the husband gives the wife a name.). Losing a husband is not good for a wife: Udovica je ka'drvo posičeno. (A widow is like a cut tree.), and the widow is no longer the best choice: Udovica podgrijana čorba, a djevojka s medom varenika. (The widow is a warmed soup, and the girl is milk with honey.), Udovica, tuda polovica. (A widow, someone else's half.). Here too, a male widow is in a better position than a female: Bolje je oca ženit negli mater udavat. (It is better to marry a father than to marry a mother.).

The family is important in the Croatian society, and it is essential to be a member of the family, which is reflected in proverbs. It is important to have a husband: Teško zemlji bez težaka, ribi bez vode, a ženi bez čovika. (It is hard for a land without laborers, for a fish without a water, and for a woman without a man.), but wife as well: Čoek na može biti čoek, dokle ga žena ne krsti. (A man cannot be a man until a woman baptizes him.). Children are important to both men and women: Bez dece je čovek okleštreno drvo, (Without children, a man is a pruned tree.), Žena bez poroda - jabuka bez roda. (A woman without childbirth - an apple without a fruit.). Parents are support in life and they always care for children: Nije prijatelja do oca $i$ majke. (There are no friends like a father and a mother.), and especially the mother: Da se matere pita, nigdar ne bi rata bilo. (If mothers were to ask, there would never be a war.). Many proverbs describe family relationships and indirectly advise on a good upbringing: Gdje je mnogo babica, kilava su djeca. (Where there are many midwives, there are ungainly children.), Umiljati otac $i$ umiljata majka slabu dicu goje. (The cuddly father and the cuddly mother raise weak children.).

Social stereotypes associated with the male-female world are primarily seen in proverbs about professions, mainly describing male jobs: Bez orača $i$ zdrava kopača ne bi bilo kruha ni kolača. (Without a plowman and a healthy digger, there would be no bread or cake.). Women, on the other hand, were tied to the house and household chores: Žena kuću drži, muž je kući gost. (The wife keeps the house, the husband is the guest of the house.), but there are also a couple of proverbs about female professions and titles: Kad je gospodarica lena, nit družina ne valja. (When the mistress is lazy, the family is not good either.), Najela se gladnica, pa se nazvala banica. (A hungry woman ate, and called herself a princess.),

In comparing proverbs with a female component, the number of proverbs with a male component is much rarer. Men are often referred to in proverbs with a female component, although they are not explicitly mentioned: $T k o$ ne ima žene, svaki je dan bije; ma tko je ima, dobro je čuva. (He who has no wife, beats her every day; and he who has it, keeps it well.), Tko nije kuću gradio i kćer udavao, ne zna što je trošak. (He who has not built a house and married a daughter does not know what the cost is.), $S$ ženama valja kako s mazgom: neće - a ti udri. (Women should be treated like a mule: if she doesn't want to - you hit.), Ljubav daj ženi, ali tajnu odaj samo majci. (Give your love to your wife, but reveal the secret only to your mother and sister.). Among proverbs with the male component, the ones with noun otac (father) prevail: Kakvo drvo, takav klin, kakav otac takav sin. (Like tree, like wedge, like father, like son.), U stara otca sirotna djeca. (In an old father orphaned children.), Bolje je oca ženit negli mater udavat. (It is better to marry a father than to marry a mother). Noun gospodar (master) is also very often: $U d o$ bra gospodara, dobar i sluga. (With a good master, a servant is also good.), Svak gospodar, a tko ce na vodu. (Everyone is the master, and who will go to the water.), Oko gospodara tusti vola $i$ konja. (Around the lord a lot of oxen and horses.), Tko ima lijepu kuću i lijepu ženu, nije gospodar od nje.(He who has a beautiful house and a beautiful wife is not the master of it.). 
Nouns čovjek (man) and $m u \check{z}$ (husband) appear as an antonym for a woman/wife, and both nouns can come in the meaning of a male adult: Bez dece je čovek okleštreno drvo. (Without children, a man is a pruned tree.), Svaka skuža ima muža. (Every excuse has a husband.), and in the sense of a married man in relation to the woman he is married to: Postelj najpredi pomiri čoveka ženom. (The bed first reconciles the man with the woman). Proverbs often have parallel structure and both wife and husband appear in the same proverb: Žena drži tri ugla kuce, a muž jedan. (The wife holds three corners of the house, and the husband one.), Žena muža nosi na licu, a mužženu na košulji. (The wife wears the husband on her face, and the husband wears the wife on his shirt.), although there is a large number of proverbs that speak only of a woman.

In general, the higher representation of proverbs with a female component denotes that a woman, even within social and value categories, was more exposed to valuation and generalization than a man. The proverbs thus reflect the gender stereotypization ${ }^{16}$ of the woman that ruled in the society when the proverbs were created. In proverbs, a woman is, as expected, a mother, a widow, a young girl for marriage, she is the protector of the house and family or on the other hand she is bad, immoral, with naughty tongue, she talks too much. On the other hand, a man is a father (good or bad), he works, he is wise, a master or, sometimes, a drunkard.

\section{Conclusion}

The analysis of the female and male world in Croatian proverbs has brought up a couple of questions. One is more sociological than linguistic - has the status of women changed? The number of proverbs used in contemporary corpora regarding male and female relations is significantly smaller than the number of collected and recorded proverbs in printed sources. It may be concluded that the status of women is changing and there is no need to address this theme through proverbs. But this thought can be assessed as somewhat superficial since, on the one hand, in everyday life, we are aware that many things are not as they should be. On the other hand, the reason for a smaller number of proverbs can be seen as the result of the rarer use of proverbs in general, as shown in the introductory part of this work. The question can be raised if the proverbs as oral (folk) literary forms are disappearing in communication. It seems to be so, but it also leads to a re-examination of the role of the recorder, as well as the essence of the proverbs itself. Is each of the collected and recorded proverbs really a proverb, generally accepted and widely used, or did the recorder sometimes write down as a proverb some wise thought uttered by a speaker (as a source of proverb), but which is not widespread and common or which is even difficult to understand? With new technologies in mind, especially corpora, another question can be raised - can corpora replace the speakers, and can new proverbs be found in the corpus? There are some typical syntactic structures that can be extracted from the existing proverbs $($ Ako ..., ...; Bolje ... nego ...; Kakav ..., takav ..., etc.) as well as lexemes that could serve as a basis of a corpus search to see if there are some thoughts and sentences which function as (new) proverbs and which do not match the existing lists of proverbs, so further research should go in that direction.

\section{R E F E R E N C E S}

1. VISINKO, K, Zvona zvone jer su potezana: primjena poslovica $u$ nastavi hrvatskoga jezika, jezičnoga izražavanja i književnosti (Profil Klett, Zagreb, 2018). — 2. ALEKSA VARGA, M, KEGLEVIĆ, A, „Iznimka potvrđuje pravilo“: Mladi i poslovice u Hrvatskoj. In: STOLAC D, VLASTELIĆ, A (Eds): Jezik i njegovi učinici. Zbornik radova s međunarodnoga znanstvenog skupa Hrvatskoga društva za primijenjenu lingvistiku (Srednja Evropa: HDPL, Zagreb, 2018). - 3. MIKIĆ P, ŠKARA, D, Kontrastivni rječnik poslovica (August Cesarec, Zagreb, 1992). - 4. KEKEZ J, Poslovice, zagonetke i govornički oblici (Matica hrvatska, Zagreb, 1996). -5. UJEVIĆ M, Narodne poslovice (Institut za etnologiju i folkloristiku, Zagreb, 2011). - 6. PULJIZ S, Memento hrvatskog jezika - narodne poslovice (Mentor, Split, 2003). — 7. HRVATSKI JEZIČNI PORTAL, https:// hjp.znanje.hr/index.php?show=search. -8 . BIRTIĆ M, BLAGUS BARTOLEC G, HUDEČEK L, JOJIĆ LJ, KOVAČEVIĆ B, LEWIS K, MATAS
IVANKOVIĆ I, MIHALJEVIĆ M, MILOŠ I, RAMADANOVIĆ E, VIDOVIĆ D, Školski rječnik hrvatskoga jezika, http://rjecnik.hr/o-rjecniku.php. - 9. ŠONJE J (Ed) Rječnik hrvatskoga jezika. (Leksikografski zavod „Miroslav Krleža”, Zagreb, 2000). - 10. CROATIAN COLLOCATION DATABASE, ihjj.hr/kolokacije/. - 11. HRWAC, Croatian Web Corpus, http://nlp.ffzg.hr/resources/corpora/hrwac/. — 12. CROATIAN LANGUAGE REPOSITORY, http://riznica.ihjj.hr/index.en.html. — 13. MILOŠ I, Hrvatski jezik, 4/4 (2017) 8. - 14. PIŠKKOVIĆ T, Feministički otpor rodnoj asimetriji u jeziku i jezikoslovlju. In: PIŠKOVIĆ T, VUKOVIĆ T (Eds): Otpor. Subverzivne prakse u hrvatskom jeziku, književnosti i kulturi. Zbornik radova 42. seminara Zagrebačke slavističke škole (FF press, Zagreb, 2014). - 15. ŠKARA, D, Glas tradicije (Ziral, Mostar/Zagreb, 1997). - LAKOFF R, Language in Society, $2 / 1$ (1973) 45. - 16. HEFFER H, Rasprave Instituta za hrvatski jezik i jezikoslovlje, 33 (2007) 165.

\section{G. Blagus Bartolec}

Institute of Croatian Language and Linguistics, Ulica Republike Austrije 16, 10000 Zagreb, Croatia e-mail: gblagus@ihjj.hr 


\section{ŽENSKI I MUŠKI SVIJET U HRVATSKIM POSLOVICAMA}

\section{S A Ž E T A K}

Poslovice kao sažete tekstne strukture primarno se određuju kao usmeni (narodni) književni oblici u kojima se iznose univerzalne misli utemeljene na pojedinačnim iskustvima prepoznatljivim i razumljivim govornicima jezične, tj. društvene zajednice u kojoj su nastale. Danas, u odnosu, primjerice, na frazeme, primjena poslovica u javnome diskursu znatno je rjeđa, a poslovice se u hrvatskom jeziku bilježe najčešće u tiskanoj formi, dok su uređeni mrežni izvori u kojima se donosi popis poslovica rijetki. Običaji, ljudske karakterne i tjelesne osobine, društvene i vjerske vrijednosti, čovjek i priroda najčešći su motivi o kojima poslovice progovaraju. Među njima, muško-ženski odnosi također su tema brojnih poslovica koje se, s obzirom na prošla vremena kad su nastale, mogu smatrati izvorom stereotipne i predrasudne slike o statusu žene i muškarca u društvu koja postoji u čovjekovoj svijesti. Na temelju poslovica sa sastavnicom žena, baba, majka, kći, sestra, cura, udovica, otac, sin, muž, sluga...) u radu se analiziraju poslovice u kojima se obrađuju muško-ženski odnosi (npr. Ljubav daj ženi, ali tajnu odaj samo majci i sestri.), odnosno koje upućuju na neku pojedinačnu osobinu koja se pripisuje muškarcu ili ženi (npr. Kakvo drvo, takav klin, kakav otac takav sin.). Analiza uključuje sljedeće: 1. izrazna (strukturna) i značenjska obilježja poslovica motiviranih muško-ženskim odnosima, 2. zastupljenost takvih poslovica u drugim leksikografskim mrežnim izvorima, 3. zastupljenost takvih poslovica u suvremenome javnom diskursu. U zaključku se raspravlja o ulozi poslovica na temu muško i žensko u suvremenom kontekstu - kakva im je perspektiva i je li korpus danas zamijenio tradicionalne zapisivače i usmenu predaju. 
